\title{
Advokasi media lokal untuk praktisi media di Kota Bandung
}

\section{Eni Maryani*, Subekti Wirabhuana Priyadharma, Preciosa Alnashava Janitra, \& Detta Rahmawan}

Fakultas IImu Komunikasi, Universitas Padjadjaran, Indonesia

*eni.maryani@unpad.ac.id

\begin{abstract}
The notion of local media was proposed in Broadcasting Law number $32 / 2002$ to support the democratic process, political decentralization and to revive the local-scale media industry. In addition, local media are also expected to be a source of relevant information for residents and the community. However, various challenges and obstacles in terms of business as well as in terms of policy continue to emerge. This community service has been carried out to journalists and local media practitioners in West Java to disseminate the results of research conducted by the team from Faculty of Communication Science, Universitas Padjadjaran on media policy and the sustainability of local media in Indonesia. In addition to disseminating research results and local media advocacy, we also conducted a Focus Group Discussion (FGD) on various issues surrounding the local media industry, and also to elaborate on the possible partnership between the academics and local media practitioners to maintain the sustainability of the local media industry in West Java. In the future, it is hoped that research collaboration and various other activities can be done consistently and long-term in nature.
\end{abstract}

\begin{abstract}
Abstrak Ide tentang media lokal tercantum dalam Undang-undang Penyiaran nomor 32 tahun 2002 untuk mendukung terwujudnya demokrasi, desentralisasi politik dan menghidupkan industri media yang berskala lokal. Selain itu media lokal juga diharapkan dapat menjadi media sumber informasi yang relevan bagi warga lokal sehingga tercipta pemberdayaan masyarakat lokal. Meskipun demikian, berbagai tantangan dan hambatan dari segi bisnis maupun dari segi kebijakan terus muncul sehingga keberlangsungan media lokal menjadi terhambat. Kegiatan pengabdian kepada masyarakat yang dilakukan kepada jurnalis dan pengelola media lokal Jawa Barat ini dimaksudkan untuk menyebarkan hasil penelitian dari tim Fakultas Ilmu Komunikasi, Universitas Padjadjaran tentang kebijakan media dan keberlangsungan media lokal di Indonesia. Selain melakukan diseminasi hasil penelitian, tim Universitas Padjadjaran juga melakukan Focus Group Discussion (FGD) perihal berbagai permasalahan yang melingkupi industri media lokal, dan juga untuk mengelaborasi kemungkinan kegiatan kolaboratif antara pihak akademisi dan praktisi media lokal terkait dengan advokasi media lokal dan untuk menjaga keberlangsungan dari Industri media lokal di Jawa Barat. Ke depannya diharapkan dapat terjalin kolaborasi riset dan berbagai kegiatan kerjasama lain yang lebih konsisten dan bersifat jangka panjang.
\end{abstract}

Keywords: local media; media industry; media management; media policy; local journalism

\section{¿ OPEN ACCESS}

Citation: Maryani, E., Priyadharma, S.W Janitra, P.A., \& Rahmawan, D. (2020). Advokasi media lokal untuk praktisi media di Kota Bandung. Riau Journal of Empowerment, 3(2), 105-116. https://doi.org/10.31258/raje.3.2.105 $\underline{116}$

Paper type: Community service

Received: 2019-12-19 Revised: 2020-07-09 Accepted: 2020-07-09

Language: Bahasa Indonesia (id)

Funding: Kegiatan Pengabdian Kepada Masyarakat Advokasi Media Lokal untuk Praktisi Media di Kota Bandung ini terlaksana dengan dana dari hibah PPM DIKTI, Kementerian Riset Teknologi dan Pendidikan Tinggi Republik Indonesia.

ISSN 2623-1549 (online), 2654-4520 (print)

(C) 2020 Eni Maryani et al. Author(s) retain the copyright of article published in this journal, with first publication rights granted to Riau Journal of Empowerment. The article is licenced under Creative Commons Attribution 4.0 International License. This license permits unrestricted use, distribution, and reproduction in any medium, provided the original author and source are credited. 


\section{PENDAHULUAN}

Indonesia sebuah negara besar yang mencakup tidak kurang dari 260 juta penduduk yang tersebar di ribuan pulau di sepanjang khatulistiwa. Indonesia juga memiliki masyarakat dengan budaya yang sangat beragam. Cakupan-cakupan wilayah yang sangat luas serta masyarakat yang tersebar dengan beragam budaya serta kondisi sosial, ekonomi maupun politik yang berbeda, maka Indonesia tidak saja membutuhkan media untuk membangun persatuan di antara warganya akan tetapi juga menghargai keragaman budaya serta beragam kepentingan sosial, ekonomi dan politik yang dimiliki warganya. Merujuk pada kondisi tersebut maka sejak tahun 1998 dengan semangat reformasi maka dibentuklah kebijakan komunikasi dan media di Indonesia yang juga semakin demokratis diharapkan tidak memarginalkan keragaman sosial, budaya ekonomi dan politik lokal dengan dominasi. Berdasarkan berbagai data riset terungkap bahwa penetrasi media penyiaran terutama televisi masih relatif tinggi. Berdasarkan riset Nielsen (2017) diketahui bahwa penetrasi televisi masih $96 \%$ dan radio 37\% sementara surat kabar dan majalah di bawah $10 \%$. Tingginya penetrasi media penyiaran menyiratkan pentingnya media penyiaran sebagai media yang dapat menerpa khalayak banyak atau masyarakat. Oleh karena itu perkembangan media penyiaran lokal menjadi penting untuk terus ditingkatkan kualitasnya sesuai dengan tujuan keberadaannya.

Menurut Undang-undang (UU) No. 32 tahun 2002 tentang Penyiaran keberadaan media lokal diharapkan dapat memberi ruang yang lebih besar terkait dengan kepentingan lokal di media. Media lokal tidak saja diharapkan berorientasi pada isu-isu lokal akan tetapi juga diharapkan dapat meningkatkan ruang untuk berkiprah bagi para praktisi media lokal. Melalui upaya tersebut maka perkembangan media lokal menjadi dasar dikembangkannya media massa yang lebih demokratis dan tidak mengukuhkan dominasi nasional atau memarginalkan kepentingan lokal. Setelah berjalan 17 tahun berlalu harapan yang terkandung dalam UU terkait dengan media lokal belum terlaksana atau terealisasi sesuai dengan harapan. Cukup banyak faktor yang menyebabkan harapan tersebut belum terealisasi sesuai dengan harapan yang ditetapkan. Praktisi media adalah salah satu pihak penting yang harus terlibat dalam mewujudkan harapan tersebut. Oleh karena itu pemahaman dan keterlibatan praktisi media menjadi penting untuk meningkatkan peran media lokal.

Artinya keberadaan media lokal tidak saja hanya dilihat sebagai institusi media akan tetapi juga harus dilihat sebagai sebuah institusi di masyarakat yang dapat menyebarkan informasi yang bersifat lokal, serta juga dapat dilihat sebagai institusi yang mempertahankan atau mengembangkan nilai-nilai budaya lokal. Meskipun demikian, praktisi media lokal masih optimis akan keberlangsungan media lokal, meskipun mereka juga mengharapkan adanya kebijakan terkait keberlangsungan media lokal yang dapat menjamin terciptanya ekosistem media lokal yang lebih sehat (Maryani et al., 2018). Terkait dengan hal ini, dibutuhkan kegiatan advokasi media lokal, terutama untuk membangun diskusi dua arah dari pihak akademisi dan praktisi media lokal, dan juga untuk membangun kegiatan kolaboratif dan berkelanjutan terkait dengan isu-isu media lokal.

Merujuk pada kondisi di atas maka upaya untuk memperluas pemahaman banyak pihak terhadap pentingnya keberadaan media lokal sesuai dengan harapan berkembangnya industri media yang sesuai dengan Indonesia. Berkembangnya Industri media lokal melalui berbagai produksi konten lokal, praktisi media di tingkat lokal, serta dukungan masyarakat lokal baik pemerintah, swasta maupun masyarakat umum lainnya. Untuk memperluas pemahaman berbagai pihak dibutuhkan serangkaian kegiatan sosialisasi dan advokasi tentang media lokal. Untuk tahun ini maka sasaran utama yang dituju dalam kegiatan pengabdian kepada 
masyarakat adalah kalangan praktisi media, sebagai salah satu pihak penting dalam sistem produksi media. Oleh karena itu Pengabdian kepada Masyarakat yang dilaksanakan diberi tema “Advokasi Media Lokal Pada Praktisi Media Lokal di Kota Bandung”. Selain itu secara khusus kegiatan pengabdian ini memiliki beberapa tujuan, yaitu (1) memberikan ruang pada praktisi media untuk mendiskusikan kebijakan media lokal dan implementasinya; (2) meningkatkan keragaman konten media lokal yang dapat mengakomodir keragaman yang dimiliki Indonesia; (3) meningkatkan pemahaman para praktisi media tentang pentingnya keterlibatan mereka dalam mengembangkan konten lokal di media lokal, dan; (4) membangun kesadaran praktisi untuk mengangkat isu media lokal untuk membangun kesadaran publik tentang media lokal.

Berdasarkan kegiatan Pengabdian Kepada Masyarakat yang dilaksanakan, maka hasil-hasil yang dapat dicapai adalah terbangunnya komunitas praktisi media yang peduli terhadap pengembangan konten lokal di berbagai media lokal. Kemudian, dapat meningkatnya pemahaman praktisi media tentang kebijakan media lokal dan implementasinya. Capaian berikutnya, yaitu meningkatkan pemahaman praktisi media tentang pentingnya keterlibatan mereka dalam mengembangkan konten lokal di media lokal. Hal lainnya yang dicapai melalui kegiatan ini adalah adanya kesadaran praktisi media untuk mengangkat isu-isu terkait media lokal untuk membangun kesadaran publik tentang media lokal.

\section{Konsep media lokal}

Dari segi historis, konsep media erat kaitannya dengan kemunculan surat kabar lokal. Surat kabar lokal berfungsi untuk menyebarkan informasi dan melayani khalayak media yang berada pada wilayah yang terbatas. Mulanya, media atau surat kabar lokal adalah bagian penting dari sebuah komunitas lokal. Hal ini terjadi karena idealnya surat kabar lokal adalah perusahaan yang "dimiliki oleh penduduk lokal, diproduksi secara lokal, mempekerjakan penduduk lokal sebagai jurnalis, menaruh perhatian pada topik pemberitaan dan dampak pemberitaan yang bersifat lokal, serta dibaca oleh masyarakat lokal" (Franklin, 1998).

Jurnalis lokal, yang bekerja untuk surat kabar lokal dapat ditemui di komunitas kecil di daerah pedesaan hingga ke kota-kota yang jauh dari pusat kota besar. Berbagai berita, informasi, hingga hiburan yang bersifat lokal telah diliput oleh jurnalis lokal yang berasal dari anggota komunitas masyarakat di daerah tersebut. Surat kabar dan jurnalis lokal telah menjadi bagian integral dari kehidupan, proses demokratisasi dan berjalannya pemerintahan lokal. Media lokal secara khusus juga mewakili wilayah-wilayah tertentu dan membantu masyarakat membayangkan diri mereka sebagai bagian dari komunitas lokal, terhubung melalui media dan berita lokal yang dekat dengan mereka, diikat bersama oleh lebih dari sekadar kedekatan geografis atau batas-batas administratif yang ditentukan secara politik. Idealnya, media dan jurnalisme lokal dapat dilihat sebagai hal yang penting dalam proses demokrasi dan pembentukan ruang publik yang relevan bagi masyarakat lokal.

Dalam kontes demokrasi, media lokal dipandang sebagai elemen penting dalam praktik politik yang bersifat lokal. Media lokal menjadi sumber informasi sekaligus wadah bagi masyarakat lokal untuk bertukar pendapat, Media lokal juga berperan penting dalam konteks pengawasan pemerintahan serta pemberdayaan warga lokal (Aldridge, 2007; Franklin, 1998; Nielsen, 2015). Seiring dengan perkembangan industri media, banyak media lokal yang dijalankan secara kekeluargaan dan turun temurun kemudian dibeli perusahaan media lain yang lebih besar dan memiliki jangkauan lebih luas, Dengan menjadi bagian dari perusahaan media lain, perubahan media lokal secara substantif lalu kerap dijalankan hanya dengan 
pertimbangan bisnis dan komersial, alih-alih relasi dan perannya dalam masyarakat lokal (Franklin, 1998).

Industri media dan jurnalisme lokal menjadi kajian yang dikembangkan di berbagai negara seperti Amerika, Inggris dan beberapa negara di Eropa (Aldridge, 2007; Nielsen, 2015). Meskipun demikian, di Indonesia kajian media lokal, terutama yang melihat dari sudut pandang industri media dan ekonomi media masih terbatas. Kajian yang umumnya dilakukan dengan konteks industri media di Indonesia cenderung meletakkan industri media nasional sebagai objek analisis. Selain itu, berbagai kajian terkait industri media di Indonesia juga sebagian besar menitikberatkan pada konteks ekonomi politik media.

Di Indonesia, hampir seluruh kelompok media besar memusatkan kegiatan bisnisnya di Jakarta. Pemusatan industri media di Indonesia, menurut beragam kajian (Armando, 2016; Eriyanto, \& Mutmainnah, 2018; Lim, 2012; Nugroho, Putri, \& Laksmi, 2012; Nugroho, Siregar, \& Laksmi, 2012; Rahayu et al., 2015; Sudibyo, 2004; Tapsell, 2018) terjadi sebagai konsekuensi yang tak terhindarkan dari kepemilikan modal yang menjadi bahan bakar utama perkembangan industri media di Indonesia. Hal ini juga terkait dengan permasalahan kebijakan media. Era reformasi yang menjadi titik awal cita-cita akan perkembangan industri media yang baik, dan demokratis, ternyata masih tidak berjalan sesuai apa yang diharapkan. Reformasi dalam perkembangannya kemudian menjadi pintu masuk peralihan kekuasaan dari otoritarianisme menuju mekanisme pasar yang oligopolis dan sangat sentralistik. Meskipun demikian, tentu media lokal masih bisa beradaptasi dan menghasilkan berbagai inovasi model bisnis yang khas sesuai dengan karakteristik masyarakat tempat media tersebut beroperasi. Oleh karena itu organisasi media dan praktisi media perlu memiliki wawasan mendalam tentang berbagai perubahan yang ada di Industri media, dan harus jeli melihat berbagai peluang untuk menciptakan nilai tambah (added value) dari media lokal.

\section{Media Lokal di Indonesia}

Bagi media-media lokal yang memiliki skala wilayah pasar lebih kecil, perubahan struktur industri media massa yang saat ini terjadi sebagai bentuk implikasi dari perkembangan bisnis media dan terjadinya proses konvergensi media tentu menjadi sebuah tantangan tersendiri. Tentunya tidak semua media lokal selalu memilih untuk bergabung dengan media lain yang lebih besar, namun kolaborasi dengan media besar tentu dipandang sebagai salah satu langkah bisnis yang dapat mendatangkan keuntungan ekonomis yang cukup besar. Dalam menghadapi ketatnya iklim bisnis media di era konvergensi, media-media lokal banyak yang mengalami kesulitan untuk tetap beroperasi karena masyarakat Indonesia telah terbiasa mengonsumsi media nasional dengan konten dan muatan nasional. Hal ini berakibat pada relatif rendahnya minat atau kecenderungan untuk melihat konten-konten lokal. Padahal, media lokal sebetulnya lebih memiliki ciri khas konten serta muatan lokal tersendiri yang dibutuhkan oleh warga setempat.

Media di Indonesia telah melalui berbagai era mulai dari perannya dalam era-era awal kemerdekaan (1945-1955), era pers yang bersifat partisan (1965-1980), hingga mulai berkembang menjadi era awal industri di tahun 1980 dan dikuasai oleh kepentingan politik di era orde baru, hingga menuju era pasca reformasi, yang banyak dipandang sebagai era dimana konglomerasi kepemilikan muncul. Industri media di Indonesia telah dikuasai oleh 12 perusahaan besar yaitu Grup MNC, Grup Jawa Pos, Kelompok Kompas Gramedia, Mahaka Media Group, Emtek (Elang Mahkota Teknologi), CT Corp, Visi Media Asia, Media Group, MRA Media, Femina Group, Tempo Inti Media, dan Berita Satu Holding. Diantara 12 media 
grup tersebut, setidaknya terdapat delapan media yang hingga tahun 2019 terus mengembangkan sayap bisnis nya dan melakukan berbagai bentuk konvergensi media dan pengembangan bisnis digital (Tapsell, 2017, 2018).

Terkait dengan media lokal di Indonesia, salah satu kajian memperlihatkan bagaimana media lokal mengalami kooptasi. Bahwa, cita-cita awal menjadikan media lokal sebagai alat yang bertujuan menciptakan masyarakat yang deliberatif, kemudian kandas, karena kepentingan politik di daerah (Yusuf, 2011). Riset lain menggambarkan bagaimana pencaplokan media lokal dilakukan oleh konglomerat media nasional di Jakarta dan dilakukan semata-mata berdasarkan strategi bisnis, seperti akusisi maupun merjer dan abai dengan peran penting media lokal bagi masyarakat lokal (Nugroho, Putri, \& Laksmi, 2012). Kajian lain secara spesifik juga telah membahas mengenai kebijakan media, yang tidak hanya gagal berimplikasi dalam industri media nasional yang sehat, namun juga gagal menghadirkan ekosistem media lokal yang sehat (Nugroho, Siregar, \& Laksmi, 2012).

Perkembangan media lokal juga cenderung menghasilkan berbagai inovasi di media lokal baik dalam hal pembuatan konten maupun dalam berbagai kegiatan yang diadakan dengan masyarakat. Idealnya, selain terkait dengan perannya sebagai sumber informasi yang relevan bagi masyarakat lokal, media lokal juga harus mengambil peran terkait berbagai potensi budaya, kesenian tradisional, maupun kearifan lokal. Penggunaan bahasa lokal, pertunjukan lagu, tarian, dan berbagai aktivitas sosial tradisional adalah bagian penting dari konten media lokal yang tentunya tidak dapat didapatkan dari media nasional. Perkembangan media lokal dalam praktik riilnya juga kerap terkena berbagai kendala dari aspek kebijakan dan bisnis. Salah satu contohnya adalah kebijakan pemberian izin penyiaran melalui seleksi dari KPID ke beberapa pengusaha media lokal sering kali bermasalah, karena setelah izin diberikan, lisensi tersebut kerap diperdagangkan secara komersial dan lalu dibeli oleh media yang memiliki jaringan nasional. Dari segi bisnis, media lokal yang mengubah kepemilikan dan beralih menjadi bagian dari media jaringan nasional kerap mengalami perubahan baik di tingkat organisasi dan konten. Kebijakan pemilik media di jaringan mereka akan sangat mempengaruhi pengelolaan media lokal. Oleh karena itu, diperlukan keseriusan untuk memperkuat dan memperluas pemahaman terkait kebijakan media untuk mendorong pengembangan media lokal secara ideal, serta perlu untuk mengkaji bagaimana media lokal beroperasi dalam konteks bisnis, yang dalam hal ini dapat dijelaskan melalui konsep ekonomi media.

\section{Konsep ekonomi media lokal}

Dalam konteks pengelolaan media, aspek manajemen, bisnis dan juga ekonomi memiliki peran krusial. Kajian ekonomi media mengacu pada semua aktivitas bisnis dan finansial terkait beragam perusahaan dalam industri media (Doyle, 2002). Pengetahuan terkait ekonomi media juga berfokus pada bagaimana perusahaan media memenuhi keinginan dan kebutuhan informasi serta hiburan dari khalayak, pengiklan, dan masyarakat dengan sumber daya yang terbatas (Albarran, 2010; Picard, 1989). Advokasi media lokal terkait praktisi media lokal ini, selain akan membahas dari segi kebijakan dan kondisi riil industri media di Indonesia, juga perlu mempertimbangkan terkait ekonomi media, yang bersifat lokal. Kajian ekonomi media menjadi salah satu cabang penting dari kajian media yang melihat bagaimana media dikelola dengan berbagai permasalahannya, dan bagaimana media harus berusaha tidak hanya mengikuti logika ekonomi dan kepentingan bisnis namun juga secara kreatif menjalankan fungsi idealnya bagi masyarakat. Ekonomi media juga akan menggali bagaimana secara 
mikro, dampak dari strategi perusahaan media yang melakukan merger, pengelolaan dan pengembangan lini bisnis dari hulu ke hilir, maupun pengembangan bisnis kepada berbagai jenis bisnis yang berbeda, seperti misalnya dengan pengembangan bisnis media yang dilakukan karena adanya disrupsi maupun potensi dari teknologi digital (Ferguson \& Greer, 2016) dan juga membahas tentang salah satu konsep penting dalam pengelolaan media modern yaitu terkait dengan aspek konvergensi media (Lugmayr \& Dal Zotto, 2016).

Bagi media lokal yang memiliki skala pasar yang lebih kecil, perubahan struktur industri media massa yang saat ini terjadi adalah implikasi perkembangan bisnis media dan terjadinya proses konvergensi media yang tentunya hal ini akan menjadi tantangan tersendiri. Tentu saja tidak semua media lokal selalu memilih untuk bergabung dengan yang media lain, yang lebih besar, tetapi kolaborasi dengan media besar jelas dilihat sebagai langkah bisnis yang dapat membawa keuntungan ekonomi yang signifikan. Dalam menghadapi ketatnya iklim bisnis media di era konvergensi, banyak media lokal mengalami kesulitan untuk tetap beroperasi karena masyarakat Indonesia cenderung terbiasa mengonsumsi media nasional dengan konten nasional minat untuk melihat konten lokal konten cenderung lebih kecil bila dibandingkan dengan media nasional. Selain itu, perlu upaya berkelanjutan bagi praktisi media lokal untuk memperkuat citra bahwa media lokal adalah bagian penting dari masyarakat lokal, dan perlu dipikirkan berbagai bentuk relasi dan hubungan yang bersifat saling menguntungkan antara media lokal dan khalayak lokal. Oleh karena itu, para pengelola atau praktisi media lokal harus mengetahui dengan cermat karakteristik konten lokal yang dibutuhkan oleh publik lokal yang menjadi khalayak mereka.

\section{METODE PENERAPAN}

Metode yang digunakan dalam kegiatan Pengabdian Kepada Masyarakat (PKM) yang bertema "Advokasi Media Lokal bagi Praktisi Media di Kota Bandung" merupakan gabungan dari beberapa teknik komunikasi.

Pertama advokasi akan dilakukan melalui metode diskusi yang difasilitasi oleh seorang fasilitator dari tim PKM Fakultas Ilmu Komunikasi (Fikom) Universitas Padjadjaran. Fasilitator akan menjelaskan mengapa kegiatan ini dilakukan dan bagaimana prosesnya. Selain itu fasilitator juga menjelaskan tujuan diskusi dan hal-hal pokok atau isu yang diharapkan dapat didiskusikan untuk membangun pemahaman bersama tentang media lokal dan keberadaannya di Jawa Barat, terutama Kota Bandung.

Kedua, diskusi yang dilakukan bersifat dialogis dan interaktif sehingga peserta menjadi aktif dalam mengemukakan pandangan atau mengomentari pandangan peserta lain. Fasilitator membantu agar alur diskusi sejalan dengan isu-isu terkait dengan tema diskusi dan dapat mencapai tujuan dilaksanakan diskusi. Selain itu penetapan waktu, alur kegiatan, dan setting duduk peserta diskusi maupun fasilitator diupayakan dapat mendukung terjadinya proses diskusi yang dialogis dan interaktif.

Ketiga, metode diskusi juga digunakan untuk membangun kesepakatan tentang pentingnya membentuk komunitas praktisi media yang peduli pada upaya untuk mengembangkan konten lokal baik secara mandiri maupun kolaborasi. Metode ini diharapkan menghasilkan sebuah komunitas yang dapat menjaga relasi praktisi media untuk menjaga keberlangsungan media lokal agar memiliki konten lokal yang lebih berkualitas dan jumlahnya juga meningkat. 
Keempat, sebagai kelanjutan advokasi dilakukan tim PKM bekerjasama dengan Ikatan Jurnalis Televisi Indonesia (IJTI) Bandung, advokasi juga terus dilakukan melalui publikasi artikel di Jurnal Pengabdian Kepada Masyarakat.

\section{HASIL DAN KETERCAPAIAN SASARAN}

Berdasarkan penelusuran pada berbagai literatur atau dokumen tentang kebijakan media ditemukan bahwa setelah reformasi terdapat perubahan yang signifikan terutama terkait dengan orientasi kebijakan media. Pertama, kebijakan di bidang media memberikan ruang yang lebih bebas bagi media untuk mengangkat beragam isu tanpa dihantui dengan kemungkinan mendapat sanksi pencabutan ijin terbit atau siaran ketika isinya bertentangan dengan pandangan pemerintah. Kebijakan terkait Surat Ijin Usaha Penerbitan Pers (SIUP) yang dapat dengan mudah dicabut oleh pemerintah, tidak lagi akan terjadi dengan dihapuskannya keharusan memiliki SIUP bagi media Pers dalam UU No. 40 tahun 1999 tentang Pers.

Perubahan signifikan juga terjadi pada kebijakan media penyiaran yaitu dengan dikeluarkannya UU Penyiaran No. 32 tahun 2002 yang secara tegas menetapkan bahwa sistem media penyiaran Indonesia dilaksanakan melalui Stasiun Siaran Lokal dan Stasiun Siaran Jaringan. Dengan kata lain sesuai dengan UU No. 32 tahun 2002 maka media siaran lebih berorientasi pada media lokal baik yang berstatus Stasiun Siaran Lokal atau Stasiun Siaran Jaringan. Stasiun Siaran Lokal merupakan stasiun yang diberikan pada pengusaha lokal dan bersiaran secara lokal atau mencakup wilayah tertentu di sebuah provinsi atau kota. Sementara Stasiun Siaran Jaringan adalah stasiun yang berada di sebuah daerah dan bekerja sama dengan berbagai stasiun siaran di berbagai daerah lainnya dalam sebuah jaringan.

Kebijakan yang berorientasi pada media lokal terkait dengan upaya untuk mengembangkan keragaman konten serta keragaman kepemilikan media di Indonesia. Hal itu ditetapkan dengan mempertimbangkan kondisi Indonesia sebagai bangsa yang memiliki cakupan wilayah yang luas serta memiliki keragaman budaya. Melalui media yang berorientasi pada sistem media lokal maka diharapkan industri media berkembang di berbagai wilayah Indonesia dan juga mendorong perkembangan industri lainnya seperti periklanan atau production house. Perkembangan tersebut juga diharapkan dapat menciptakan peluang kerja dalam bidang industri media dan komunikasi di berbagai daerah.

Berdasarkan penelitian terkait dengan kebijakan media dan keberlanjutan media lokal dalam perkembangan industri media di Indonesia, ditemukan bahwa realisasi dari ketetapan Undang-undang tersebut tidak terlaksana dengan baik. Terdapat berbagai penyimpangan yang terjadi dalam kasus media lokal di Palembang, Bandung dan Manado. Diketahui bahwa para pemilik stasiun penyiaran yang berkedudukan di Jakarta dan tidak dapat lagi bersiaran secara nasional kemudian membuat stasiun jaringan di berbagai wilayah termasuk di tiga kota yang diteliti. Selanjutnya stasiun jaringan lokal yang dimiliki pengusaha nasional di ketiga daerah tersebut didominasi dengan isi siaran yang diproduksi di Jakarta dan disiarkan di semua stasiun jaringan yang mereka miliki. Artinya konten siaran yang diproduksi di Jakarta dengan segala isu yang terkait dengan kondisi masyarakat Jakarta mengisi $80-90 \%$ konten stasiun jaringan. Menurut penjelasan para pengelola stasiun jaringan sebagian besar konten tersebut juga diproduksi oleh stasiun pusat yang berada Jakarta, artinya tidak diproduksi oleh stasiun jaringan dan juga tidak melibatkan sumber daya manusia di daerah tempat stasiun jaringan tersebut berada. 
Berdasarkan analisis terhadap praktik implementasi kebijakan media lokal dalam bentuk stasiun lokal dan stasiun jaringan atau juga media jaringan dalam media cetak menghasilkan dua hal penting, yaitu dibutuhkan kesadaran praktisi media dan publik terkait dengan keberadaan media lokal dan harapan yang terkandung dalam kebijakan tentang media lokal dalam UU. Selain itu untuk menjaga keberlangsungan media lokal dengan keragaman konten membutuhkan pengembangan model manajemen media lokal dan model bisnis media lokal serta mengembangkan konvergensi media dengan penggunaan media sosial. Salah satu hal penting lainnya adalah perlu adanya upaya dari para praktisi media lokal untuk mengangkat isu tentang pentingnya media lokal serta konten lokal. Penyebarluasan isu tersebut melalui media diharapkan dapat meningkatkan kesadaran publik tentang pentingnya keberadaan media lokal. Kesadaran publik diharapkan dapat melahirkan dukungan publik pada para praktisi media untuk memperjuangkan konten lokal di media lokal serta menjaga kelangsungan media lokal yang memiliki relasi kuat dengan masyarakat lokal di tempat media lokal tersebut beroperasi.

Merujuk pada fenomena yang dipaparkan di atas maka diperlukan upaya untuk membangun kesadaran para praktisi media lokal di Bandung tentang keberadaan media lokal baik berupa media cetak jaringan, stasiun siaran jaringan maupun stasiun siaran lokal. Berdasarkan tujuan tersebut maka tim PKM Fikom Universitas Padjadjaran merancang dan melaksanakan advokasi tentang media lokal bagi praktisi media di Kota Bandung.

Sesuai dengan tujuan advokasi media lokal yaitu membangun kesadaran para praktisi media maka kegiatan advokasi yang dilakukan menggunakan format diskusi yang bersifat interaktif. Untuk menghadirkan para praktisi media di Kota Bandung maka Tim PKM Fikom Universitas Padjadjaran bekerjasama dengan Ikatan Jurnalis Televisi Indonesia (IJTI) Jawa Barat dan wartawan senior Surat Kabar Pikiran Rakyat. Kerjasama ini berhasil melibatkan 12 Praktisi Media di Kota Bandung, dan Dosen serta Mahasiswa Fikom Universitas Padjadjaran di Program Sarjana dan Program Pascasarjana.

Keseluruhan peserta yang terlibat dalam kegiatan advokasi berjumlah 22 orang. Kegiatan PKM diselenggarakan di sebuah ruangan berbentuk Saung di sebelah Kantor IJTI Jawa Barat, tepatnya di Jl. Bekonik No 25 Bandung. Seperti yang tampak di dalam Gambar 1. para peserta duduk melingkar dan berhadapan sehingga semua peserta terlibat langsung dalam interaksi yang terjadi.

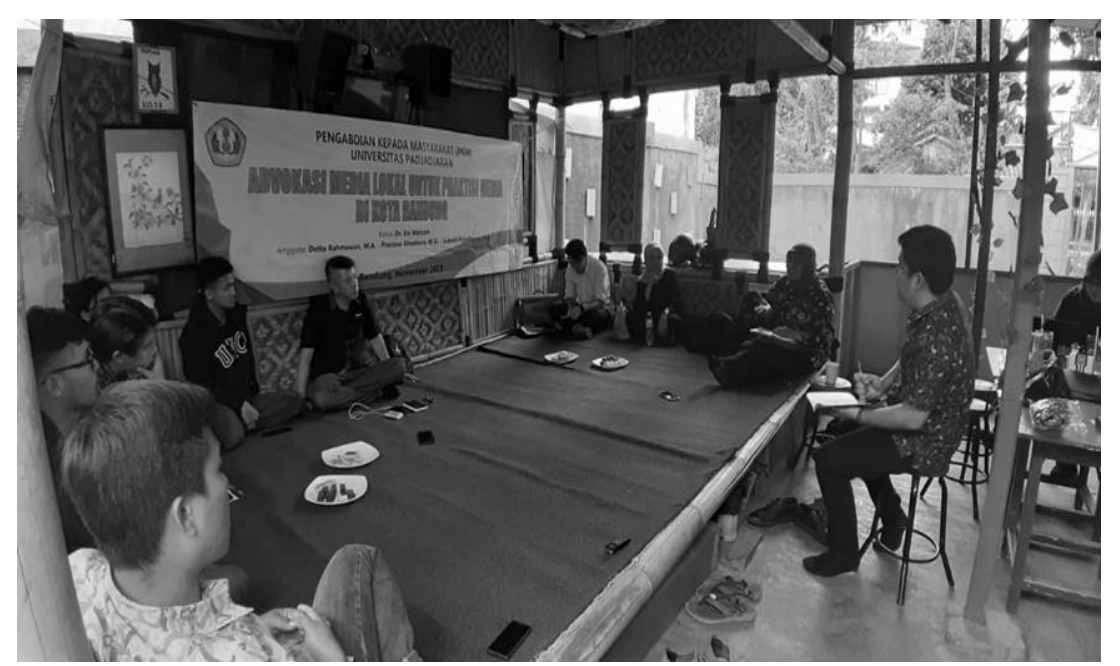

Gambar 1. Kegiatan advokasi media lokal bagi praktisi media di Kota Bandung dalam sesi paparan dari fasilitator 
Proses diskusi yang difasilitasi oleh seorang fasilitator seperti tampak dalam Gambar 1, berjalan dengan lancar dan dalam suasana yang akrab serta santai tapi serius. Setting tempat, posisi duduk peserta dan suasana diskusi terbukti merangsang keaktifan peserta diskusi untuk mengemukakan pendapat atau saling mengomentari pendapat peserta lainnya.

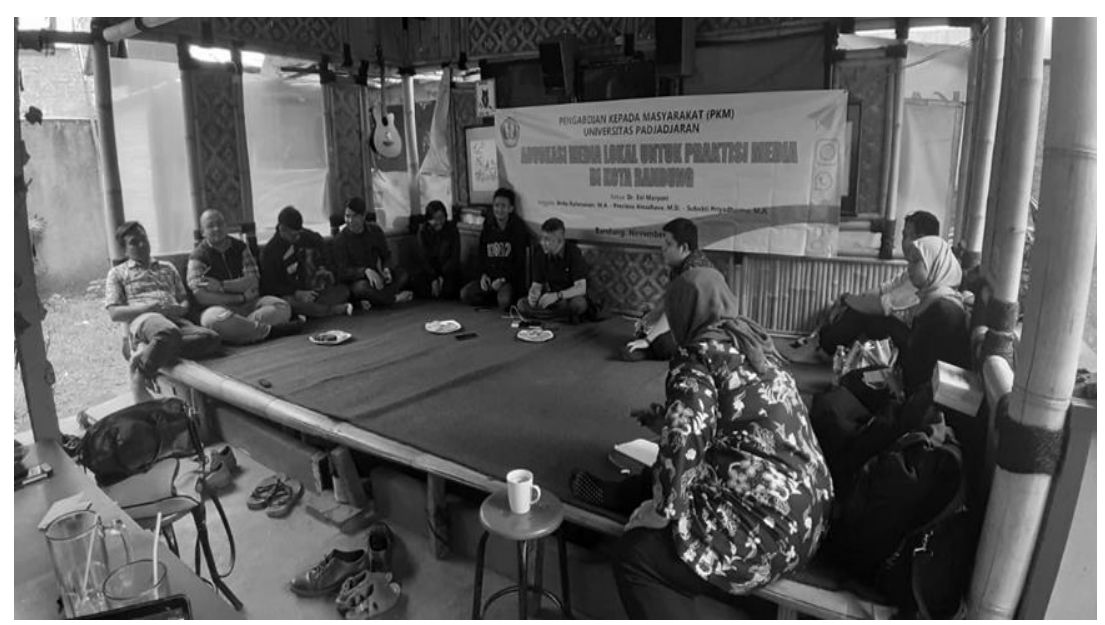

Gambar 2. Kegiatan advokasi media lokal bagi praktisi media di Kota Bandung dalam sesi diskusi

Gambar 2 menunjukan posisi fasilitator telah berpindah dari duduk di kursi kemudian duduk bersila di antara peserta diskusi sehingga semakin mendekatkan fasilitator dengan para peserta diskusi dan perbincangan semakin akrab. Gambar 2 juga memperlihatkan perhatian peserta diskusi terfokus pada diskusi bukan saja karena posisi duduk mereka tapi mereka juga tidak terganggu perhatiannya oleh berbagai hidangan makanan atau aktivitas makan minum peserta. Acara ini sebelumnya telah diawali dengan acara makan siang dan minum kopi serta makanan kecil saat mengobrol sebelum diskusi dimulai. Artinya secara fisik maupun psikologis peserta diskusi juga sudah diperkirakan cukup siap untuk berdiskusi.

Kegiatan Pengabdian Kepada Masyarakat yang dilaksanakan dalam format diskusi terbukti memberikan keleluasaan pada para peserta untuk terlibat aktif atau menyimak setiap pandangan yang dilontarkan peserta lain atau pertanyaan-pertanyaan yang diangkat oleh fasilitator. Peserta diskusi yang terdiri dari para praktisi media di Kota Bandung, Dosen, Mahasiswa Pascasarjana dan Sarjana Fikom Universitas Padjadjaran berlangsung interaktif sejak jam 14.00 WIB sampai jam 16.30 WIB.

Terdapat beberapa hal penting yang diperbincangkan yaitu isu-isu tentang masalahmasalah yang dihadapi oleh praktisi dan usulan atau pemikiran terkait masalah tersebut. Sebagai contoh disepakati peserta diskusi bahwa terdapat kecenderungan di media-media lokal termasuk di Bandung adanya eksploitasi terhadap para praktisi media dengan adanya beban sebagai jurnalis dan juga diminta membantu bidang marketing medianya. Berdasarkan diskusi disepakati bahwa hal itu pada dasarnya mengganggu independensi para jurnalis dalam melakukan liputan atau membuat pemberitaan. Sebagai pekerja para praktisi media merasa kurang memiliki kemampuan atau kekuatan untuk menolak kebijakan yang ditetapkan media tempat mereka bekerja. Untuk menyikapi hal tersebut disepakati dalam diskusi bahwa seharusnya Dewan Pers atau Komisi Penyiaran Indonesia (KPI) dapat menetapkan kebijakan untuk melarang media menugaskan jurnalis sebagai marketing medianya. Kebijakan yang ditetapkan serta pengawasan yang dilakukan oleh ke dua lembaga tersebut diharapkan dapat melindungi jurnalis dari penugasan rangkap tersebut. 
Selain itu disepakati pula bahwa perlu diusahakan agar publik memahami beragam isu terkait dengan kebijakan atau permasalahan yang dihadapi dalam implementasi kebijakan UU terkait dengan media lokal. Publik perlu memahami permasalahan media lokal misalnya terkait dengan dukungan iklan yang sangat terbatas bagi media lokal karena umumnya kebijakan terkait iklan dari berbagai lembaga ditetapkan di Jakarta. Adanya pengetahuan dan kesadaran publik terkait dukungan iklan terhadap keberlangsungan media lokal dapat menjadi dasar untuk mengembangkan model bisnis media lokal yang melibatkan partisipasi publik lokal dalam bentuk dukungan-dukungan dana untuk mengembangkan konten lokal di media lokal.

Oleh karena itu maka disepakati adanya kerjasama lebih lanjut antara pihak perguruan tinggi dengan para praktisi media yang dapat difasilitasi oleh Ikatan Jurnalis Televisi Indonesia Jawa Barat, di Bandung. Ketua IJTI Jawa Barat menyatakan kesediaannya untuk membantu dan memfasilitasi kolaborasi antara pihak perguruan tinggi dan praktisi media lokal di Jawa Barat khususnya di Kota Bandung. Salah satu kolaborasi yang diharapkan dapat diwujudkan adalah kolaborasi untuk terus memperjuangkan keberlangsungan media lokal yang berpihak pada kepentingan publik lokal.

Keterlibatan kaum perempuan sebagai praktisi media lokal di Kota Bandung bukan sesuatu yang aneh karena keterlibatan mereka juga tidak kalah dari praktisi media laki-laki. Resti adalah salah seorang praktisi media yang aktif selama diskusi untuk berbagi pengalamannya di radio siaran dan memberi masukan terhadap pengembangan manajemen atau model bisnis media lokal. Diskusi juga mengangkat isu tentang ikatan atau bentuk kerjasama antara pengelola atau praktisi media lokal berjaringan dengan pengusaha nasional pemilik media jaringan.

Beberapa isu penting lainnya yang dibahas adalah terkait dengan tantangan untuk mengembangkan penggunaan media sosial oleh media lokal untuk menjangkau khalayak baru khususnya khalayak remaja atau muda. Melalui media sosial diharapkan akses khalayak remaja atau generasi digital terhadap media lokal dapat ditingkatkan. Kendala dalam penggunaan media sosial adalah masih kurangnya kesadaran pihak manajemen terkait pentingnya media sosial dan pengembangannya termasuk konten-konten lokal. Performa media sosial dalam yang dimiliki beragam media lokal juga menjadi salah satu pembahasan yaitu dalam bentuk diskusi.

Kegiatan advokasi media lokal bagi praktisi media di Kota Bandung pada akhirnya ditutup pada jam +17.00 WIB. Selain membangun kesadaran bersama tentang pentingnya media lokal para praktisi juga menyadari diperlukan adanya kerjasama para praktisi media dengan berbagai pihak. Kegiatan diakhiri dengan kesepakatan kerjasama di waktu yang akan datang terkait dengan penelitian atau kegiatan Pengabdian Kepada Masyarakat. Selain itu kepada seluruh peserta di akhir kegiatan tim PKM membagikan sertifikat sebagai bukti partisipasi aktif mereka dalam kegiatan ini.

\section{KESIMPULAN}

Kebijakan media pasca reformasi 1998 yang lebih terbuka dan berorientasi kepada kepentingan publik pada proses implementasinya mendapat banyak kendala dan tantangan. Salah satu masalah yang cukup penting adalah keberadaan media lokal yang diharapkan dapat lebih mengakomodir kebutuhan masyarakat Indonesia yang beragam dan tersebar di wilayah yang luas. Keberlangsungan media lokal yang berkembang saat ini tidak mencerminkan upaya 
untuk mengembangkan keragaman isi (diversity of content) dan keragaman kepemilikan (diversity of ownership). Berdasarkan penelitian tentang keberlangsungan media lokal di kota Bandung, Palembang dan Manado disimpulkan perlu adanya kesadaran para praktisi media tentang peran media lokal yang seharusnya diperjuangkan serta dibutuhkannya dukungan publik terhadap keberlangsungan media lokal.

Berdasarkan temuan tersebut maka diperlukan upaya untuk membangun kesadaran para praktisi media lokal dan menyepakati berbagai sikap dan tindakan untuk memperjuangkan keberlangsungan media lokal yang lebih baik. Untuk itu maka advokasi media lokal bagi praktisi media lokal di Kota Bandung menjadi sangat diperlukan. Merujuk pada keperluan itu maka Tim PKM Fikom Universitas Padjadjaran melakukan advokasi tersebut dalam kegiatan Pengabdian Kepada Masyarakat untuk melakukan Advokasi tersebut terhadap praktisi media di Kota Bandung.

Berdasarkan tujuan yang ingin dicapai maka pelaksanaan advokasi dirancang dalam bentuk diskusi dengan suasana dialog yang dipandu oleh fasilitator. Kegiatan berjalan lancar dan sesuai dengan tujuan yang diharapkan dari diskusi ini diperoleh beberapa kesepakatan. Diskusi ini pertama, menyepakati dibutuhkannya peran aktif dan kerjasama para praktisi media untuk berkolaborasi dalam memperjuangkan keberlangsungan media lokal baik untuk melakukan advokasi kebijakan maupun melakukan perubahan di bidang manajemen media lokal. Kedua, diskusi ini juga melahirkan kesepakatan untuk membangun kesadaran publik dan dukungan publik untuk memperjuangkan media lokal yang dapat menjaga keberlangsungannya secara ekonomi akan tetapi juga berorientasi pada kepentingan publik lokal.

\section{UCAPAN TERIMA KASIH}

Kegiatan Pengabdian Kepada Masyarakat Advokasi Media Lokal untuk Praktisi Media di Kota Bandung ini terlaksana dengan dana dari hibah PPM DIKTI, Kementerian Riset Teknologi dan Pendidikan Tinggi Republik Indonesia. Selain itu kami juga mengucapkan terima kasih kepada pihak Universitas Padjadjaran yang telah mendukung terselenggaranya kegiatan ini.

\section{Daftar Pustaka}

1. Albarran, A.B. (2010). The Media Economy. Routledge.

2. Aldridge, M. (2007). Understanding the Local Media. Open University Press.

3. Armando, A. (2016). Televisi Indonesia - Di Bawah Kapitalisme Global. Kompas Media Nusantara.

4. Doyle, G. (2002). Understanding Media Economics. SAGE Publications Ltd.

5. Eriyanto, \& Mutmainnah, N. (2018). Indonesia - Media Landscape. https://medialandscapes.org/country/indonesia

6. Ferguson, D. A., \& Greer, C. F. (2016). Reaching a Moving Target: How Local TV Stations are Using Digital Tools to Connect with Generation C. International Journal on Media Management, 18(3-4), 141-161. https://doi.org/10.1080/14241277.2016.1245191

7. Franklin, B. (Eds.). (1998). Local Journalism and Local Media. Routledge.

8. Lim, M. (2012). The league of thirteen: Media concentration in Indonesia. Participatory Media Lab \& The Ford Foundation. 
https://www.academia.edu/7282028/Lim_M._2012_The_League_of_Thirteen_Media_Conce ntration_in_Indonesia

9. Lugmayr, A., \& Dal Zotto, C. (Eds.). (2016). Media Convergence Handbook - Vol. 1: Journalism, Broadcasting, and Social Media Aspects of Convergence. Springer-Verlag Berlin Heidelberg.

10. Maryani, E., Karlinah, S., \& Rahmawan, D. (2018). The Sustainability of Local Media Within the Domination of National Media Industry. E3S Web of Conferences, 73, article 14010. https://doi.org/https://doi.org/10.1051/e3sconf/20187314010

11. Nielsen, R. K. (Eds.). (2015). Local Journalism: The Decline of Newspapers and the Rise of Digital Media. I.B Tauris.

12. Nugroho, Y., Putri, D.A., \& Laksmi, S. (2012). Memetakan Lansekap Industri Media Kontemporer di Indonesia. Centre for Innovation Policy and Governance.

13. Nugroho, Y., Siregar, M.F., \& Laksmi, S. (2012). Memetakan Kebijakan Media di Indonesia. Centre for Innovation Policy and Governance.

14. Picard, R. (1989). Media Economics: Concepts and Issues. SAGE Publications Ltd.

15. Rahayu, Wahyono, B., Rianto, P., Kurnia, N., Wendratama, E., \& Siregar, A. E. (2015). Menegakkan Kedaulatan Telekomunikasi dan Penyiaran di Indonesia. PR2Media \& Tifa.

16. Sudibyo, A. (2004). Ekonomi Politik Media Penyiaran. Institut Studi Arus Informasi (ISAI) dan Lembaga Kajian Islam dan Sosial Jakarta.

17. Tapsell, R. (2017). Media Power in Indonesia: Oligarchs, Citizens and the Digital Revolution. Rowman \& Littlefield International.

18. Tapsell, R. (2018). Kuasa Media di Indonesia: Kaum Oligarki, Warga, dan Revolusi Digital. Marjin Kiri.

19. Yusuf, I.A. (2011). Media Lokal dalam Konstelasi Komunikasi Politik di Daerah. Jurnal Ilmu Sosial dan Ilmu Politik, 14(3), 297-316. https://doi.org/10.22146/jsp.10930 